\title{
The only game in town
}

Om Stanley Fishs læser-respons teori

"Interpretation is the only game in town."

Stanley Fish

\section{Stanley Fish}

Tidsskriftet Kritik inviterede i 1985 en række nordiske forfattere til at indsende et portræt af den - forestillede eller faktiske - »læser« de skriver til, når de skriver. Grunden til dette initiativ var to bidrag til tidsskriftet, der havde det til fælles, at de begge i overvejende grad fokuserede på læseren. Det ene var en novelle af Jens Smærup Sørensen, det andet en introduktion til den amerikanske litteraturteoretiker Stanley Eugene Fish (f.1938) af Hans Hauge. ${ }^{1}$ Det var tilsyneladende især sidstnævnte, der havde sat skub i redaktionen (Poul Behrendt, Johs. H. Christensen og Klaus P. Mortensen), for invitationen til forfatterne indledtes med den betragtning, at der inden for amerikansk litteraturkritik er

»opstået nogle nye teorier omkring forholdet mellem læser og forfatter. Her rejses blandt andet det spørgsmål, hvorvidt den litterære tekst overhovedet eksisterer, eller om den udelukkende er et produkt af den kontekst, hvori den indgår hos læseren. At den har én betydning i en kirke. En anden betydning i et klasseværelse. En tredie hos en freudianer. Og slet ingen selvstændig betydning, ifølge Stanley Fish. « ${ }^{2}$

Reaktionen udeblev ikke. Udover at levere sine læser-portrætter, kommenterede en stor del af panelet Stanley Fishs standpunkt, og dette skete med ret stor enighed: Selvfølgelig findes der litterære tekster (hvad er det ellers man som forfatter sidder og laver?). F.eks. skrev Henrik Nordbrandt:

»De, der idag stiller spørgsmålet om, hvorvidt den litterære tekst eksisterer eller ej, er åndelige efterkommere af dem, der for nogle år siden 
skrev afhandlinger om englenes vaner etc. Idioter er altid blevet modtaget med åbne arme - også på parnasset. $\aleph^{3}$

Stanley Fish ville formentlig ikke tage sig denne - noget uvelkomne - modtagelse særligt nært. Han møder den nemlig ofte. Hvis vi f.eks. vender blikket fra de »skabende« mod de »teoretiserende og kritiserende «, finder vi en lignende uforståenhed og slåen sig for panden. Således betegner Pil Dahlerup i sin introduktion til dekonstruktionen hans teori som »en nyere udgave af en gentagen kulturkamp: de uproduktive overtager de produktives arbejde og udgiver det for deres eget $\aleph^{4}-$ med direkte reference til den patriarkalske religion og kapitalen. En anden dansk »anti-fishianer«, professor Jørgen Dines Johansen, afslutter en længere kritik af Fish med den betragtning, at teorien burde medføre, »at de der hylder en sådanne opfattelse ophørte med at fortolke. De geråder nemlig i en art eksistentiel selvmodsigelse eller reducerer sig selv til pjat, såfremt de ikke mener, at have gode grunde til at tolke teksten på én måde snarere end på en anden. $\aleph^{5}$

Stanley Fish kategoriseres normalt sammen med den flok af amerikanske litteratur- og receptionsteoretikere, man samler under fællesnævneren »readerresponse theory «, og som ud over Fish tæller navne som Norman Holland, Jonathan Culler, Michael Riffatere m.fl. Fishs hovedpåstand kan sammenfattes til følgende: Teksten er intet, læsningen er alt. Og med læsning mener Fish interpretation. Når man synes at hente betydning, struktur, mening etc. ud af en tekst tager man fejl, for disse er strategier man allerede er i besiddelse af, inden man påbegynder læsningen. Det vil sige, at fortolkningen konstituerer teksten som et betydende fænomen, hævder Fish. Synspunktet kan virke radikalt (for ikke at sige »rabiat «) - især hvis man ikke tager den teoretiske udvikling Fish har gennemgået med i sine betragtninger. Og dette synes i høj grad, at have været tilfældet for ovennævnte kritikere. ${ }^{6}$

Is There a Text in This Class $?^{7}$ er en samling af essays skrevet i perioden 1970-79, og bogen præsenterer og dækker denne udvikling. Essayene er delt i to grupper, hvor den første bærer overskriften »Literature in the Reader «, og den anden »Interpretive Authority in the Classroom and in Literary Criticism«. Første del anskueliggør den position »den unge« Fish havde og viser udviklingen mod budskabet i anden del, som derved kommer til at fremstå som en statusopgørelse over, hvor han er nået til i sin teoretiske udvikling (i 1980). Samlingens budskab er derfor langt fra homogent, men ved hjælp af en fyldig introduktion og en række reflekterende og diskuterende kommentarer til de enkelte essays, tager bogen form af en kontinuerlig indkredsen af en receptionsorienteret tekstovervejelse, der bedst kan betegnes med bogens undertitel: De interpretative fællesskabers autoritet. ${ }^{8}$ 
Når Fish på denne måde lader sin bog rumme flere forskellige positioner af sit eget virke, er det blandt andet for at bevise netop påstanden om de interpretative fællesskabers autoritet. Et af hans standpunkter er, at enhver litteraturteori altid præsupponerer de strategier, strukturer, etc., den hævder at finde i tekster, og dette viser han ved at påpege de fejl han gør i sit tidligere arbejde: Den teori han dengang udviklede og troede på, viste ikke noget $i$ teksten, men var udelukkende et udtryk for en læsestrategi, han lagde ned over den.

\author{
»If the study of literature arises from \\ our concern with texts, there can be no \\ denying the importance of what happens \\ to us through these texts. «
}

Wolfgang Iser

\title{
Affective Stylistics
}

Det var nu ikke fordi Fishs tidlige læsestrategi var en traditionel litteraturanalytisk fremgangsmåde. Tværtimod var hans opmærksomhed fra starten rettet mod læserens rolle i teksten.

I 1967 præsenterede han i bogen Surprised by $\operatorname{Sin}^{9}$ en kontroversiel analyse af 1600-tals digteren John Miltons store epos Paradise Lost. Fish hævder, at Miltons tekst $i k k e$ (som ellers antaget) primært handler om syndefaldet, men derimod om læseren. Og hvad mere er: Milton har villet det sådan. Fish viser $i$ et utal af eksempler, hvordan læseren gennem læsningen bringes til at tvivle på sine egne iagtagelser og reaktioner over for teksten: Det ene øjeblik siger den ét, mens den umiddelbart efter synes at sige noget andet; den er et $\gg$ selfconsuming artifact«, der æder sig selv op, for til slut at lade læseren tilbage med den indsigt, at det netop er manglen på entydighed og stabilitet i læsningen, som er dens fokus. If $\varnothing$ lge Fish genskaber Milton syndefaldet i læserens tanker, for derefter at lade læseren falde, på samme måde som Adam gjorde. Miltons formål med destruktionen af læserens selvsikkerhed er en religiøs nedbrydning og efterfølgende genopdragelse, der gør læseren opmærksom på sin egen synd. Tekstens betydning opstår - så at sige - i et samspil mellem Miltons intention og læseren, men med læserens oplevelse som kilden til meningen.

Når man tager højde for det tidspunkt bogen udkom på, kan det ikke undre, at den mødte en del modstand. Nykritikken dominerede stadig de litteraturteoretiske og -kritiske miljøer, og man fornægtede enhver sociologisk, biografisk 
og historisk tilgang til tekster. Nærlæsningen var et centralt begreb, og den æstetiske norm for et værk var, at det var en organisk struktureret helhed af form og indhold; en autonom enhed af spændingsfyldte modsætninger. W.K. Wimsatt og M.C. Beardsley havde formuleret begreberne $»$ the intentionel fallacy $\ll$ og »the affective fallacy«, og Fish blev beskyldt for at falde for begge, da han dels hævdede, at det var Miltons intention at teksten skulle virke på ovenfor beskrevne måde (læsningen bestod $i$ at gå ind $i$ teksten på forfatterens betingelser), dels havde sin analytiske opmærksomhed vendt mod læserens affekt.

Men trods hård kritik placerede bogen alligevel Fish i den litteraturteoretiske debat, hvilket der kan være flere grunde til. For det første var 1967 så absolut at betegne som nykritikkens sensommer, og bogen har sikkert derfor virket som en forfriskende nyhed. For det andet knyttede Fish udelukkende sin analysestrategi til dette ene Miltonværk, idet han hævdede at den centrale placering af læseren var unik for Paradise Lost, hvorfor det har virket mere tilforladeligt, at han foretog den tolkning han gjorde.

Men sådan forblev det ikke: Foranlediget af en henvendelse fra tidsskriftet New Literary History, skrev Fish i 1970 essayet $»$ Literature in the Reader: Affective Stylistics «; et essay der meget vel kan betragtes som et manifest for hans tidlige projekt. Eller måske burde man rettere sige »projekter«, for der er nærmere tale om to forskellige diskurser i Fishs arbejde på dette tidspunkt. Det ene er afsløringen af teksten som et »self-consuming artifact« og det andet som er af mere overvejende grad - er forholdet mellem tekst og læser. Essayet er derfor også et langt stykke af vejen et forsøg på at generalisere de resultater, han var nået frem til i Milton-bogen, og opmærksomheden er vendt mod læserens aktiviteter, for at afkode og bestemme hvilke processer en læsning indeholder. I stedet for at spørge efter hvad tekster betyder, vil han finde ud hvad tekster $g \phi r$.

Som sagt indebar en sådanne drejning flere opgør med nykritikkens formalistiske grundlag. For det første gør Fish læserens affekt primær, og opponerer derved imod det synspunkt, at teksten er et selvtilstrækkeligt gemmested for en mening (autonomien); i stedet for at tale om en »affectiv fallacy « udvikler han en »affective stylistics«, hvor det netop er læserens reaktion, der er central. For det andet bemærker Fish, at nykritikken (og for den sags skyld andre formalistiske retninger), i kraft af at den betragter teksten som en helhed, fordrer at meningen først træder frem ved afslutningen af læsningen. Hertil indvender Fish, at læsning er en bevægelse, et forløb i tid, og at meningen dermed ikke er en endelig, fast faktor, men rettere en »meaning experience Basis for metoden er således den overvejelse, at man som læser ikke responderer på en »samlet« tekstoplevelse, men derimod på det flow læsningen er. 
For ikke at ende i en subjektivisme, i stil med tidligere tiders impressionistiske læserbeskrivelse, lancerer Fish begrebet »den informerede læser«, som er en konstruktion af hvad den ideelle læser måtte være. Fish opstiller tre krav: 1) Læseren må være en kompetent taler af det sprog teksten er bygget af. 2) Læseren må være i fuld besiddelse af den semantiske viden en moden lytter har brug for, for at opnå forståelse. 3) Læseren skal have litterær kompetence, hvormed menes en erfaring der dækker alt fra de mest almindelige litterære modeller til kendskabet til hele genrer. Den faktiske læser, som fors $\emptyset$ ger at læse som den informerede læser, skal dermed prøve (såvidt det er muligt) at frigøre sig fra sin situation (»jeg'et«) og forsøge at »objektivere« sin synsvinkel, for dermed at gøre sig klart, hvad det er teksten gør ved ham/hende. Der er dog ikke tale om, at man foretager en decideret objektiv læsning, men rettere en kontrolleret subjektiv. I praksis gælder det hovedsageligt om, at man sætter sin læsehastighed ned, og forsøger at notere sig de »hændelser«, man normalt vil »overse«, men som alligevel optræder i læsningen. I denne metode kan ingen sætninger tilsidesættes, for selv de mest ordinære og entydige sætninger skal afkodes, da netop entydigheden også har en betydning. At vi uden videre forstår en ordinær sætning gør den ekstraordinær, hvilket andre analysemetoder synes at ignorere, da de opererer på så højt et abstraktionsniveau, at de grundlæggende elementer i menings-oplevelsen bliver negligerede og/eller fordrejede. Fishs læsning kan ses som en videreudvikling af nykritikkens nærlæsning; blot meget tættere, og udelukkende orienteret mod, at aflæse læserens affekt i løbet af lasningen. ${ }^{10}$ Han opsummerer metoden til følgende:

»(1) den nægter at besvare eller så meget som stille spørgsmålet om, hvad dette værk handler om; (2) den giver en analyse ikke af formelle træk, men af læserens reaktioner som de udvikler sig i relation til ordene, sådan som de følger efter hinanden i tid; (3) resultatet vil være en beskrivelse af reaktionsstrukturen, som vil have en usymmetrisk [..] eller måske oven i købet kontrasterende relation til strukturen af værket som en ting i sig selv« (ITTC p.42).

Derved har Fish givet begrebet »mening « en anden betydning "end den gængse opfattelse: Den information en »udtalelse« giver - dens meddelelse - er konstitueret af dens mening, men kan ikke identificeres med denne. Derimod er »meningen « »oplevelsen« af en ytring - og ikke hvad der kan siges om den. Det samme kan derfor heller ikke udtrykkes på to forskellige måder, da meningen så at sige ligger i den lingvistiske oplevelse. Men grundlaget for dette projekt er ikke ukompliceret, for hvis en teksts mening kan aflæses som Fish gør det, da forudsættes det, at alle læsere har et sammenfaldende plan, hvor 
læseoplevelserne er fælles. Fish gør selv opmærksom på (ITTC p.5, p.45), at teorien har rødder i Noam Chomskys tese om »lingvistisk kompetence«, der angiver at vi har et fælles sprogsystem, som er uafhængigt af forskelle i uddannelse og kultur, ${ }^{11}$ og som lader os forstå og producere sætninger vi ikke tidligere har mødt. Fish slutter heraf, at et fælles sprog også må give basis for en fælles forståelse. Men dette medfører, at alle læsninger af samme tekst hermed må være ens - hvilket ikke just synes at være tilfældet. Denne »hurdle« kommer Fish over ved at dele læsningen i to planer, hvor det første plan er selve oplevelsens (experience), som er fælles for alle læsere, mens andet plan er en intellektualisering eller interpretation af den første (faktiske) oplevelse. Dvs. at en formalistisk kritiker, når denne udøver sit virke, oversœtter den umiddelbare oplevelse (første plan) til det vokabularium kritikeren selvbevidst holder sig til (nykritikken, strukturalismen etc.), hvorved forskellige analyser kommer til at virke divergerende. Men i bund og grund er de altså ens.

Fishs pointe er, at via hans metode foretager man den egentlige analyse af en tekst: nemlig beskrivelsen af det første plan. Han hævder altså at sætte sig ud over de formalistiske analysemetoder, ved at lade læserens oplevelse komme i højsædet og praktisere en kritik, der egentlig ikke er nogen metode, da hverken dens resultater eller dens færdigheder er overførbare. Det er rettere en af-sløring ${ }^{12}$ af, at der foregår mere i sproget end vi umiddelbart lægger mærke til. Den er et redskab der aldrig bringer læseren frem til »pointen« $\mathrm{i}$ en tekst, men gør opmærksom på, hvad teksten $g \phi r$ ved læseren. Og netop at den $g \varnothing r$ det, er dens mening.

Hvis man betragter Fishs affektive stilistik som en påvisning af nykritikkens mangler, er den fortrinlig. Men anskuet som en tekstanalytisk metode er den langt fra så ukompliceret, som den umiddelbart kan virke. Spørgsmålet er, om Fish egentlig er så frigjort fra formalismen, som han gerne vil gøre sig?

Et stort problem er, at han på den ene side ønsker at gøre op med formalismen ved at koncentrere sin opmærksomhed omkring lceseren, men på den anden side hævder, at hans metode (via kontrolleret subjektivitet) beskriver den egentlige betydning af en tekst (læsningernes fælles (første) plan). På den ene side vil han altså noget radikalt nyt, men på den anden bruger han teksten, som »facit-liste« - på samme måde som formalismen. Mod anklager om blot at være formalisme i en ny udklædning vil Fish dels henvise til, at hans teori er om læseren, og dels at formalismen er indkalkuleret $\mathrm{i}$ hans teori; men tilh $\emptyset-$ rende anden del af læsningen: interpretationen. Altså ville han hævde, at formalisterne (eller »almindelige« læsere) faktisk læser ligesom ham, men bare ikke er bevidste om det - en temmelig svag argumentation. Samtidig hævder Fish, at resultatet af de formalistiske analyser bestemmes af den teori, der ligger bag (oplevelsen (første plan) oversættes til teoriens vokabular og strategi). 
Dette virker selvmodsigende, for han siger også, at man via hans »metode « når frem til den egentlige mening med teksten, men er denne metode ikke bestemmende for, hvordan hans resultat bliver?

Dette tager en anden læser-responsteoretiker, Jonathan Culler, fat på med udgangspunkt $\mathrm{i}$ ideen om teksten som et »self-consuming artifact «: »Hvis man skulle tage den opfattelse alvorligt, at han beskriver og analyserer sin oplevelse af at læse disse tekster, ville vi snart blive stillet over for den kendsgerning, at han aldrig lærer noget ved at læse. ${ }^{13}$ Fish påviser i tekst efter tekst, at læseren starter med en slags forventninger ansporet af første halvdel af sætningen, for derefter at forvirres af, at det modsatte kommer til udtryk $i$ anden halvdel. Cullers pointe er, at en normal læser, i stedet for gang på gang at overraskes over tekstens nedbrydning af hans intellekt, ville indstille sin læsning herpå, således at han forudgriber den selv-destruktive bevægelse i teksten, og læser den som indløsning af hans forventninger. ${ }^{14}$

Fish siger selv om sin tidlige position:

»Jeg bevægede mig kort sagt i to (uforenelige) retninger på én gang: på den ene side blev formalismens hegemoni bekræftet, ja endda udvidet, ved at teksten blev gjort ansvarlig for sine læseres aktiviteter; på den anden side blev disse samme aktiviteter tildelt en større og større rolle $i$ et sådant omfang, at der undertiden blev stillet spørgsmålstegn ved selve tekstens eksistens « (ITTC p.8.).

I første omgang løser han problemet ved at sætte sig ud over den tvedeling han indtil videre har betragtet læsningen som, ved at konkludere at selve udvælgeIsen af lingvistiske/tekstuelle fakta, på det han betegnede som første plan, bliver styret af den interpretative strategi, der vil komme til udtryk på andet plan. Han skelner altså stadig mellem et beskrivende og et fortolkende plan, men det fortolkende er bestemmende for hvordan det beskrivende plan arter sig, og dermed falder de to planer sammen til et; det interpreterende. Derved imødegår han den kritik, der blev rejst $\mathrm{i}$ det foregående om at hans affektive stilistik og teorien om teksten som et »self-consuming artifact « faktisk måtte være bestemmende for, hvorledes hans analyser blev. Ideen om dels, at læseren altid er »hovedaktøren« i en skønlitterær tekst, og dels, at man er i stand til at nå en form for »sandhed « vedrørende teksten, er hverken mere rigtig eller forkert end de metoder, han forsøger at gøre op med.

Interpretationen får altså en større og større plads i Fishs verden. Men han ser stadig tekst og læser som to uafhængige og stabile størrelser. Der er lingvistiske og tekstuelle facts, som læseren »møder« og vælger mellem i læsningen. Men denne skelnen begynder at smuldre i et essay fra 1973 behandlende 
forskellen mellem ordinært og litterært sprog. ${ }^{15}$ Essensen i essayet er, at den skelnen man normalt har sat mellem ordinært og litterært sprog ikke eksisterer, men at det ordinære sprog er lige så værdifuldt, dybt etc., som det litterære. Men hvis der ikke er noget formelt kriterium for hvad en litterær tekst er, hvorledes identificerer man så en sådan? Fishs svar herpå er, at litteratur er en konventionel kategori, og hvad der bestemmes som litteratur, er resultatet af en »aftale« inden for en afgrænset gruppe af læsere. Udtrykt anderledes: Litteratur er et produkt af en bestemt måde at læse på. En sådanne påstand giver selvfølgelig en hel række følger. F.eks. kan en teksts litterære status ændres med tiden, eller være svingende forskellige læsergrupper imellem, og alle æstetiske normer er dermed lokale konventioner i stedet for universelle og eviggyldige »love«. Dermed bliver litteratur- og astetikhistorie en empirisk videnskab i stedet for en teoretisk. Umiddelbart kunne dette lyde som et udtryk for den totale subjektivisme, men dette modarbejder Fish ved ikke at tillægge det enkelte subjekt definitionen af litteraturen. Derimod henviser han til det fællesskab subjektet er en del af, som bestemmende for de »regler « han/hun læser efter, og dermed for hvilke tekster han/hun læser som litteratur.

»Mes vers ont le sens qu'on leur prête«

Paul Valery

\section{The only game in town: De interpretive fallesskaber}

Det er dog først i essayet »Interpreting the Variorum « fra 1976, at han eksplicit fjerner distinktionen mellem tekst og læser. Essayet er delt i tre. I første del udfører han en »affektiv stilistik«-analyse efter den model, som er skitseret i ovenstående; derefter diskuterer og kritiserer han sin egen analyse med henblik på at vise, at den ikke er en analyse, men en interpretation; og endelig diskuterer han hvad læsning egentlig er og færdigformulerer ideen om de interpretive fællesskaber.

Fish bestemmer i første omgang sin egen analyse til at være et fors $\emptyset \mathrm{g}$ på at beskrive læserens oplevelse, og dermed også hvad forfatterens intention har været. Eller formuleret anderledes; »hvad mine analyser alt $i$ alt går ud på er beskrivelser af en succession af beslutninger truffet af nogle læsere vedrørende en forfatters intention« (ITTC p.161). Dette åbner for to indvendinger. Den første er, at proceduren er cirkulær, forstået sådan at Fish forsøger at beskrive en læsers oplevelse, der i sin strategier svarer til en forfatters intention (som det også var tilfældet i Milton-bogen), og denne intention specificerer han ved at henvise til de strategier læseren finder i teksten. Men at kunne komme med 
denne indvending kræver, at man kan separere intention og forståelse fra hinanden, så de står som to uafhængige størrelser. Dette mener Fish ikke er muligt og bestemmer dem i stedet til at være to sider af en konventionel handling, som hver især betinger den anden. Den anden indvending ligner den første, for hvis indholdet $\mathrm{i}$ en læsers oplevelse er at finde frem til forfatterens intention, er dette da ikke det samme som at teksten indeholder og producerer alt? Og vil det ikke være ensbetydende med, at Fish igen indtager en formalistisk (nykritisk) position? Hertil svarer Fish, at intentionen, så at sige, skabes af interpretationen - i stedet for omvendt. Når han selv sætter sig for at beskrive hvad en tekst gør ved en læser - hvilket er det samme som forfatterens intention har han allerede taget de interpretative briller på, der lader ham læse denne struktur.

Herved falder læserens oplevelse, de formelle enheder og intentionens struktur sammen til én og samme sag, hvorfor spørgsmălene angående prioritet og uafhængighed overhovedet ikke opstår. Men der opstår et andet spørgsmål: Hvis intention, form og læserens oplevelse blot er forskellige måder at referere til samme interpretative handling, hvad er denne handling da en interpretation af? Dette kan Fish ikke svare på, men påpeger samtidig, at det er der heller ikke andre der kan, for man kan ikke sætte sig ud over sit selv og betragte en tekst »objektivt«. De formalistiske analyser hævder, at de kan finde frem til strukturer, der er uafhængige af fortolkningen, men disse strukturer varierer alt efter af hvem og hvornår de udføres. Fishs konklusion er derfor, at de strukturer formalisterne beskriver er konstitueret af den interpretative handling.

Fish har derved givet interpretationen en altovervejende status i kraft af, at enhver »aflæsning « (som ikke længere er en aflæsning) er en interpretation. Selv når man sætter sig for at aflæse grammatiske eller fonetiske mønstre i en tekst, opstår disse i interpretationen. Dette er ikke ensbetydende med, at de ikke eksisterer, men eksistensen er kun en realitet i kraft af den menneskeskabte interpretative model, der har kaldt dem til live. Når man sætter sig for at udføre en grammatisk analyse af en given tekst, vil denne normalt $i k k e$ betragtes som en interpretation, men derimod som aflæsningen af noget faktisk. Men der findes forskellige grammatiske teoribygninger man kan tage i brug, og disse fører ikke nødvendigvis til det samme resultat. Altså er der tale om interpretationer, som er konsensusstyrede.

Den traditionelle læsning (forstået som den rene perception) er blevet erstattet af interpretationen. Eller formuleret anderledes: Læsning er interpretation, hvilket giver muligheden for at tale om en ny-kritisk læsning, en strukturalistisk læsning, en dekonstruktiv læsning etc. Dette er dog ikke ensbetydende med, at en fortolkning (eller læsning) er et overgreb på teksten. Tværtimod, 
for teksten bliver først til $i$ læsningen. Dermed ikke sagt, at der ikke eksisterer tekster, forstået som en intenderet meddelelse printet i et skriftsystem på et stykke papir. Men selve denne meddelelse er også et resultat af en interpretation; nemlig interpretationen af et lingvistisk system, et skriftsystem, en æstetisk norm etc., der igen skal interpreteres af læseren. Betydning er dermed ikke præfabrikerede former, der kan overføres fra en afsender til en modtager. Derimod aktiveres betydningen hos modtageren gennem den interpretative strategi denne vælger (eller er »dømt til) at bruge; formen bliver til hos modtageren. Det afsendere giver modtagere (eller læsere) er muligheden for at skabe mening (eller tekster) ved at få dem til at iværksætte en eller flere interpretative strategier. Dette er dog ikke ensbetydende med, at teksten alligevel bærer »noget«; ej heller retningslinierne for hvordan meningen skal skabes (hvordan de interpretative strategier skal sættes i gang). »Sporene « vil kun være for de læsere, der i forvejen er i besiddelse af de interpretative strategier. »Sporene« vil altså ikke producere en strategi, men rettere være produktet af en.

»En forfatter vover sin projektion, ikke på grund af noget »i« sporene [the marks], men på grund af noget han antager befinder sig i hans læser.

Selve eksistens af »sporene« er en funktion af et interpretativt fællesskab, for de vil kun blive genkendt (d.v.s. produceret) af dettes medlemmer. De, som befinder sig uden for dette fællesskab, vil anlægge et andet sæt af fortolkningsstrategier (fortolkning kan ikke undgås) og vil derfor producere en anden slags spor« (ITTC p.173).

Selve læsningen (læs: interpretationen) er dermed åben. To læsere kan læse den samme tekst forskelligt, mens to andre læsere kan læse den ens. En læser kan også læse to forskellige tekster ens, ligesom han/hun kan læse dem forskelligt. Umiddelbart kan dette ligne den rene relativisme og subjektivisme, men det er det ikke, for - som det nævnes i ovenstående citat - er det ikke subjektet der bestemmer læsningen. Enhver læsning har rod $\mathrm{i}$ et eller flere fællesskaber, der er bestemmende for hvilke strategier og strukturer læseren lægger ned over teksten (hvilke »mærker« der skabes i den). Disse interpretative fælleskaber er ikke stabile, men vokser og formindskes konstant (læserne skifter fællesskaber); der er altid grænser mellem fællesskaberne, men de er ikke mere permanente end at de tillader ændringer, diskussioner, overskridelser etc.

Men hvor finder vi disse strategiers basis? Dette spørgsmål gør Fish ikke ret meget ud af, men konkluderer blot: »Evnen til at fortolke er ikke tilegnet; den er konstituerende for det at være menneske $«(I T T C$ p.172). Det, at vi er intelligente væsener, er årsagen til at vi fortolker. Hvad der derimod er blevet erhvervet, er måderne at interpretere på, og disse måder kan glemmes, andres, 
udskiftes etc., hvorved der sker en korresponderende ændring i teksternes betydningsstruktur, da det vil være andre spor vi dermed lægger ind i dem.

Lad os se på nogle af konsekvenserne af ovenstående. Den i en tidligere sammenhæng nævnte Poul Behrendt leger - til trods for dyb mistro - med på Fishs præmisser og antager, at Fish har ret; at der vitterligt kan laves forskellige læsninger af én og samme tekst, og at det er meningsløst at udnævne den ene læsning som bedre end den anden. Men hvad Fish da glemmer, hævder Behrendt, »er at den ene freudianske læsning ikke kan være lige så god som den anden. At den ene sociologiske læsning ikke kan være lige så god som den anden. Og at der altså inden for en given formålssammenhæng findes en consensus, som ikke tillader at kalde den ene læsning lige så god som den anden. $\ll^{16}$

$\mathrm{Nu}$ vil den, som har fulgt godt med i det indledende sikkert bemærke, at dette har Fish sådan set $i k k e$ glemt. For at kunne foretage en freudiansk læsning er det (logisk nok) først nødvendigt at tilegne sig Freuds teorier og at gøre dette indebærer en lossning af Freud eller - for at tale Fishiansk - rettere en interpretation. Hvis vi tager Fish på ordet og - som Behrendt - leger med, da må konsekvensen være, at der principielt heller ikke er nogen forskel på »rigtigheden « af de freudianske læsninger indbyrdes. Det er rigtigt som Behrendt gør opmærksom på, at man inden for det interpretative fællesskab vil være af en ganske anden overbevisning, og hævde at der findes Freudlæsninger der er bedre (eller rigtigere) end andre, men fællesskabet vil ændre sig og justere sine strategier med tiden, hvorfor tidligere læsninger vil blive udraderede af nye.

Dette rejser et andet spørgsmål: Hvordan kan det være, at vi inden for et fællesskab betragter nogle læsninger som værende bedre end andre? Hvorfor kan vi overbevises om, at andres læsninger er bedre end vores, når den læsning, vi har præsteret, udelukkende er et udtryk for strategier $v i$ har aktiveret? Det centrale begreb her er retorik. Hvor den traditionelle litteraturanalytiker/kritiker normalt vil betragte sin praksis som et forsøg på at overbevise andre om, at hans eller hendes læsning er den rigtige, vil dette ifølge Fish ikke være andet end en overtalelse, en forførelse. Når »interpretation is the only game in town « (ITTC p.355) er det klart nok, at den der kender det interpretive spils regler bedst (den der virker mest hjemmevant i den interpretive strategi) bedst vil kunne overbevise andre deltagere om, at han/hun er bedre til spillet end de $\emptyset v$ rige deltagere. Og forstår denne »topspiller « over for spillere, der spiller efter andre regler, at præsentere de regler han/hun spiller efter som »bedre « end deres (at vise, at deres indeholder mangler og fejl, som udbedres ved $\gg$ topspillerens« sæt (ligesom Fish hævdede, at han kom uden om ny-kritikkens problemer med sin affektive stilistik), kan disse spillere evt. overtales til at deltage i det nye spil eller udvikle nye regler. Men forandringer er altid frem- 
bragt og indoptaget inden for spillets regler; d.v.s. inden for de rammer der angiver, hvad konsensus lader tælle som en succesfuld argumentation eller modargumentation.

Men sætter teksten da overhovedet ingen grænser for fortolkningens udfald? Eksisterer begreber som fejl- eller overfortolkning ikke længere? Hertil vil Fish svare både ja og nej. Hvis man spørger ham som person (som medlem af et interpretativt fællesskab, hvis strategi er en affektiv stilistik), da vil han hævde, at der findes fejlfortolkninger, for der vil være (eller komme) massevis af fællesskaber, som ligger så fjernt fra Fishs, at han ikke vil kunne forstå deres vokabularier, deres strategier etc. Man kunne forestille sig en læser over for Fish ville hævde, at Miltons Paradise Lost hverken er om syndefaldet eller om læseren (som Fish argumenterer for), men derimod om det danske fodboldlandshold vej mod EM-guldet sommeren 1992. Denne læsning vil Fish ganske givet se som forkert, men kun ud fra den betragtning, at den falder uden for konsensus med hensyn til hvordan vi i dag læser tekster fra 1600-tallet. Pointen er, at de mekanismer der forkaster læsninger ikke har grundfæste i teksten, men derimod i de ( $\mathrm{i}$ forhold til konsensus) herskende interpretative strategier, som producerer teksten.

Umberto Eco er tilsyneladende af en lidt anden mening. På et seminar ${ }^{17}$ angående forholdet mellem fortolkning og overfortolkning, har »fishianeren « Richard Rorty (Rorty betegner sig selv som sådan i sit oplæg), for at demonstrere mangfoldigheden i og brugsværdien af tekster, opstillet et eksempel over, hvor mange forskellige ting en skruetrækker kan bruges til. Eco, som mener, at teksten selv sætter grænser for hvordan den kan læses, opsummerer og indvender: »Rorty gav udtryk for, at jeg kan bruge en skruetrækker til at dreje på en skrue, til at åbne en emballage og til at klø mig i øret«. Men, tilføjer han så, »jeg kan ikke bruge den som et askebæger. $^{18}$

Man må uvilkårligt give Eco ret. En skruetrækker er god til mange ting, men den er ret elendig som askebæger; eller som telefon for den sags skyld. På samme måde er Søren Kierkegaards Enten-Eller ikke videre velegnet som teknisk vejledning for, hvordan man bygger sin egen flyvemaskine. Hverken Rorty eller Fish vil formentlig være uenige med Eco, men deres begrundelse vil være, at Ecos eksempel slet ikke er en interpretation. ${ }^{19}$ Således siger Fish i Is There a Text in This Class? i forbindelse med en argumentation for, at man ikke kan foretage interpretationer, der ligger uden for »spillet«:

»Man kan ikke afbryde spillet, fordi en hvilken som helst fortolkning, man fremlægger, uansat hvor »absurd« den er, vil allerede være med i spillet (ellers ville man ikke engang kunne opfatte den som en fortolkning); og man kan ikke komme ud af spillet, fordi hvad som helst man 
gør (enhver opfattelse af en tekst man fremsætter) kun vil kunne genkendes inden for de betingelser spillet har etableret.« (ITTC, p.358; min understregning)

Et af Fishs eksempler på, hvorledes en given teksts betydning svinger alt efter hvad sammenhæng den præsenteres $i$, er en situation fra hans undervisning (ITTC p.322 ff.). Han skal have to forelæsninger i træk i samme lokale. Den første er om chomskiansk transformationsgrammatik, og Fish stiller navnene på nogle af de vigtigste personer ${ }^{20}$ op på tavlen. I stedet for at viske dem ud inden næste hold (som følger et kursus i 1600-tals digtning, og som formentlig intet kender til Chomsky-skolen) kommer, laver han en ramme derom, og skriver et sidetal ved. Han fortæller det nye hold, at teksten de ser på tavlen er et digt fra det 17. århundrede, de skal analysere i timen, og holdet gennemfører en analyse af teksten ud fra denne overbevisning.

Det Fish bl.a. viser med eksemplet, er det interpretative fællesskabs autoritet - med ham selv som »demagogen «. Når de studerende ankommer til undervisningen, er de allerede klar over, hvad det er der venter dem. De er så at sige bevidste om, hvilket fællesskab de befinder sig i: Et fællesskab, hvor man analyserer digte fra 1600-tallet ud fra en strategi, der er skabt inden for en akademisk litteraturhistorisk tradition. Og når Fish stiller dem over for et analyseobjekt, aktiverer de deres strategi(er) og ekspliciterer den(/dem).

Lad os udvide eksemplet lidt. Man kunne forestille sig, at den undervisning der havde været i lokalet inden Fish ankommer, havde været for et hold fysikstuderende og omhandlet termodynamik, hvorfor tavlen bærer en tekst bestående af nogle grafiske modeller. Er dette tilfældet, ville Fish kunne »bruge denne tekst, hvis han ønsker at anskueliggøre katastrofeteorien ${ }^{21}$ for sit hold. Og det selv om teksten har haft et andet formål oprindeligt. Videre kunne man antage, at Fish slet ikke ved hvilken undervisning, der har været i lokalet tidligere, men at det normalt bliver brugt til litteraturteoretisk undervisning. Tilfældet er dog, at førnævnte hold fysikstuderende er blevet undervist i termodynamik i lokalet, og når Fish ankommer med sit litteraturteoretiske hold, bliver han stillet over for spørgsmålet om, hvad det er for en tekst der står på tavlen. Fish vil ud fra »konteksten « (et lokale der normalt benyttes til litteraturundervisning), bestemme teksten som en model til illustration af katastrofeteorien, og vil forklare denne ud fra teksten. Der vil selvfølgelig være elementer, han ikke helt kan få til at passe ind i sammenhængen, på samme måde som han finder, at visse andre behøver en dybere forklaring, end den der umiddelbart træder frem på tavlen, men dette »udbedrer « han blot gennem sin »analyse« (læs: læsning). Teksten får en betydning og både Fish såvel som studerende er glade og tilfredse. 
Men er teksten dermed ikke fejllæst? Den har jo fået en anden betydning end den oprindeligt havde? Ikke ifølge Fish, for der er skabt en meningsgivende helhed ud af den. De forskellige spor er knyttet sammen til en betydningsstruktur via hans interpretative strategi. Den er altså rettere $»$ fejl-forlæst «, ved at Fish har en anden indgang til den, end den fysikholdets underviser havde, da denne skabte teksten.

En kort opsamling. Inden teksten bliver interpreteret er den kun en overflade, og den dybde vi synes at finde deri, er ikke i teksten, men i os selv. Dermed ikke sagt, at den ikke oprindeligt havde en intention, for den er selvfølgelig også skabt inden for et interpretativt fællesskab, men det er kun i kraft af vores egen forbindelse eller kendskab til dette interpretative fællesskab, at vi overhovedet har muligheden for at forstå denne. I samme åndedræt skal det igen bemærkes, at ovenstående ikke er ensbetydende med, at vi ikke kan kommunikere, for det kan vi. Men vi kan aldrig sige med sikkerhed om den betydning, vi mener at tilegne os fra en tekst er sammenfaldende med den betydning afsenderen havde til hensigt, at teksten skulle have. Kort sagt: Der er en tekst, men alt det vi siger om den, er udelukkende udtryk for interpretative strategier, tilhørende de fællesskaber hvori vi har rod. Og dette er gæidende, hvad enten vi forstår eller misforstår afsenderens intention.

At sproget selv véd noget er en forrygende metafor, men $\mathrm{i}$ bedste fald vidunderligt nonsens.

Harold Bloom

\section{Det dekonstruktive fallesskab}

Den periode som Fish udviklede sin teori i var (i amerikansk sammenhæng) i høj grad præget af dekonstruktionen, men Fish tilhører nærmere neo-pragmatismen; en strømning som er uafhængig af og har en anden oprindelse end dekonstruktionen, men som alligevel har mange fællestræk med denne.

Den gamle strukturalist Tzvetan Todorov er blandt dem, der har draget sammenligning mellem neo-pragmatismen og dekonstruktionen. I et essay med titlen »Mod antihumanismen i litteraturkritikken ${ }^{22}$ betegner han neopragmatismen som mindre alvorlig og mere naiv end dekonstruktionen, men lader dem begge gå ind under betegnelsen »post-strukturalisme«, da de har en fælles rodfæstning i Nietzsches værdikritik (og derfor kan betegnes som "post-moderne $\ll) .{ }^{23}$ De forsøger ifølge Todorov at gøre op med

»på den ene side de universelle værdier, retten, etikken; på den anden 
side sandheden, erkendelsen, videnskaben. De har berøringsflader til det samme: det der afsløres af den mere eller mindre åbent vedkendte lovprisning af styrken (vi er ikke så langt fra Harold Bloom, en anden militant nietzscheaner) og det der forbinder dem med den subjektive idealisme (verden eksisterer ikke i sig selv, kun i min perception). $\ll^{24}$

Hvad enten man er enig eller uenig med Todorovs »retoriske stillingtagen« til de to strømninger, må man medgive ham, at han faktisk fanger deres sammenfald ganske godt - med undtagelse af kategoriseringen som »subjektiv idealisme.« Det er common sense for Fish (og for neo-pragmatismen mere generelt), at verden eksisterer »derude «, og at den gør det uafhængigt af os; at vi ikke er årsagen til dens eksistens. Men dette er ikke ensbetydende med, at vi kan bruge verden som målestok for, hvad der er sandt eller falsk. Sandhed er noget man skaber, snarere end noget man finder. Dette bygger på en konstatering af, at hvor der ikke er sætninger, er der ingen sandhed. Og da sætninger ikke er uden et sprog og sproget er menneskeskabt, er sandheden også menneskeskabt. Verden eksisterer altså uafhængigt af os, men det gør vores beskrivelse af den ikke, og det er kun disse, der kan være sande eller falske; verden er ikke nogen af delene i sig selv.

Dekonstruktionens ${ }^{25}$ syn på menneskets forhold til verden er meget lig dette: Jacques Derridas udtryk »Il n'y a pas d'hors texte« bliver tit (mis)forstået, som om han benægter eksistensen af andet end tekster; at han betragter verden som en bog. Men det er ikke lige det, han har ønsket med sit generaliserede tekstbegreb. ${ }^{26}$ Når Derrida har betegnet alt muligt som tekster (politiske systemer, kunst, filosofi, teori, naturvidenskaben etc.), og samtidig hævdet, at der ikke er noget uden for teksten, har det været for at vise, at vi ikke kan komme til nogen form for objektiv erkendelse; at vi er fanget af den vestlige metafysik (bl.a. etno-, fono- og logocentrismen). Vi har ingen adgang til verden i sig selv, men kun som tekst; som den måde vi »læser den på«.

Man kan drage en parallel til Fishs idé om, at vi ikke kan sætte os uden for de interpretative fællesskaber; selv hvis vi forsøger at indtage en relativistisk eller »ultra-skeptisk « position, vil den altid have rod i et fællesskab; en strategi. Man kan sige, at vi ikke kan identificere os med tomhed, eller indtage tomhedens plads, da dette vil være ensbetydende med fjernelsen af identitet. Og identitet er nødvendig for at være skeptisk. Derrida arbejder på et lignende grundlag, men med den tilføjelse, at de interpretative fællesskaber (hvis vi altså oversætter ham til fishiansk) er underlagt en foelles strategi, der kommer til udtryk via den vestlige metafysik. Og ligesom Fish ønsker at vise, at vores tolkninger og analyser, blot er udtryk for interpretative strategier vi lægger ned over teksten, ønsker Derrida, at afsløre denne metafysik. 
Når teksten er frigjort eller løsrevet fra kontekst, intention, recipient etc. sagt anderledes: når teksten kun er i sin materialitet eller tekstualitet - betegner Derrida den som $» s k r i f t \ll{ }^{27}$ Skriften er altid løsrevet fra sin oprindelse. Den er intet i sig selv udover en abstrakt åbenhed, en overflade, som kan kopieres i en uendelighed uden at ændres. Men et af Derridas projekter er at fastholde denne skrift via dekonstruktionen (jvf. grammatologien), uden at gøre sig nogle hermeneutiske forudsætninger. Man kan sige, at Derrida vil forsøge at sætte sig ud over de interpretative fællesskaber for at finde ud af, hvad skriften egentlig er. Dekonstruktionen er altså en pre-tekstuel læsning, man ikke foretager for at fortolke, men for at vise sprogets uafgørlighed. Som jeg var inde på tidligere, betragter Fish dette træk som umuligt, da de tekstlige spor - så at sige - opstår hos læseren. Og Fish vil derfor sikkert blot kategorisere Derridas forsøg, som endnu en læsning, samt hævde at den »skrift« Derrida evt. ville finde frem til, blot er et udtryk for en interpretativ strategi, der forsøger at sætte sig udover hermeneutikkens, fænomenologiens og strukturalismens problemer. ${ }^{28}$

Et andet af dekonstruktionens projekter - som det kommer til udtryk hos Jacques Derrida - er at dekonstruere subjekt-objekt dikotomien, og dette gør Fish $^{29}$ netop ved at erfare, at det hverken er teksten eller læseren, der konstituerer betydningsproduktionen i læseakten, men derimod de interpretative fællesskaber. Han siger selv herom:

»[...] betydninger vil hverken være subjektive eller objektive, i det mindste ikke sădan som det antages af dem, som argumenter inden for den traditionelle ramme: de vil ikke være objektive, fordi de altid vil være produkt af et synspunkt snarere end de enkelt vil være »læst frem «; og de vil ikke være subjektive, fordi dette synspunkt altid vil være socialt eller institutionelt «(ITTC p.335).

Eller man kunne sige, at betydninger er både subjektive og objektive, da de tilhører en bestemt synsvinkel [subjektiv], som samtidig ikke er individuel men konventionsbestemt [objektiv].

Der synes altså at være mange sammenfald mellem Derridas dekonstruktion og Fishs projekt. Men hvordan ser det ud, hvis man sammenligner Fish med den litterære dekonstruktion? Fra Derrida overtager denne erkendelsen af, at teksten er uafgфrlig, og stiller sig således i opposition til de formalistiske tekstteorier, for uafgørligheden er ikke det samme som polysemi. I formalismen har der været tendens til at betragte polysemien som et æstetisk kriterium (giver teksten mulighed for mange analyser, er den en »god « tekst), men dette gør ikke teksten mindre afg $\emptyset$ rlig. Uafg $\emptyset$ rligheden fremtræder ved, at en tekst siger to forskellige og inkompatible ting på en gang; den dekonstruerer sig 
selv. I dette kunne man synes, at der er et sammenfald mellem Fish og dekonstruktionen; men en grundlæggende forskel er synsvinklen. Dekonstruktionen vil gennem sine læsninger udgrænse denne uafgørlighed og derved afsløre og eksplicitere den. Fish vil hævde, at denne afsløring ikke er andet end udtryk for en interpretativ strategi, der er blevet aktiveret $\mathrm{i}$ »mødet« med teksten, og at de mønstre den måtte synes at »afsløre« $i k k e$ er mønstre i teksten, men derimod i læsningen. Det vil sige, at Fish - når dekonstruktionen hævder at tekster dekonstruerer sig selv - vil svare bekræftende, men samtidig påpege, at de kun gør det blandt de læsere, som er med i det dekonstruktive fællesskab. Og her er den grundlæggende forskel. For Fish er det læsningen som er åben og ustabil. For dekonstruktionen er det teksten.

Et andet kendetegn ved dekonstruktion (eller den post-strukturalistiske tænkning mere generelt), er nivelleringen af grænserne mellem genrer: mellem fiktion og teori, litteratur og filosofi etc. Denne ser Fish - som nævnt tidligere - også, men igen er der forskel i argumentationen. Forskellen er her, at dekonstruktionen hævder denne opløsning allerede indeholdt i teksten, mens Fish vil sige, at den grænse, man normalt har trukket, har været et resultat af de interpretative fællesskabers konventioner. Når man nu synes at erfare, at denne skelnen ikke har været reel, da er det igen et resultat af fællesskabernes konventioner. Dekonstruktionen synes altså at kunne realisere visse betragtninger angående teksten, med direkte reference til samme, mens Fish tillægger disse betragtninger det fællesskab, dekonstruktivisterne tilhører. Men igen skal det påpeges, at dermed $e r$ de også i teksten, for uden en læser er teksten intet. Den har ingen betydning før den tillægges en.

"Hvis du ikke ved hvad meningen er med dit liv da er det meningen."

Poul Borum

\section{Er der liv efter Fish?}

Fishs teoretiske udvikling kan beskrives som en bevægelse fra et forsøg på at skabe en sprogorienteret litteraturteori som opgør med nykritikken, til formuleringen af en meta-teoretisk overvejelse med et post-moderne/post-strukturalistisk fundament. Det er en bevægelse, der har medført, at han fra at tro på, at teksten havde en værdi i sig selv, gik mod den erkendelse, at tekstens betydning udelukkende er et resultat af den kontekst - eller det fællesskab den modtages i. Og dermed er alle teoretiske overvejelser angående »sandhed « gjort til diskurser, hvor den ene ikke er mere »rigtig « end den anden - men 
samtidig heller ikke mere forkert.

En typisk indvending mod Fish er, at hvis vi ikke kan sige noget om en tekst, hvorfor så overhovedet dyrke »institutionel læsning «? Hvorfor opretholde de litterære fag på universiteterne, hvis disses aktiviteter overhovedet ingen videnskabelig værdi har? Eller man kunne drage problematikken lidt længere og spørge, om konsekvensen af et standpunkt som Fishs ikke er, at man helt vil holde op med at fortolke?

Denne modløshed kan mødes med et par mod-spørgsmål. Hvorfor har vi egentlig analyseret? Ændrer det på vores oplevelse af litteratur, at vi erkender, at det ikke er teksten, der gør noget ved os, men os der gør noget ved teksten?

Dette for at påpege to ting. For det første har Fish ret i, at den ene læsning principielt ikke er bedre end den anden - ikke hvis man betragter læsningen af litteratur som et vigtigt led i menneskets søgen efter svar, helhed, overskuelighed og identitet. Men dette er ikke ensbetydende med, at den litterære institution ingen værdi har. Indgangsvinklen til den er blot lidt anderledes end hidtil antaget, for dybest set må det være underordnet, om det vi »læser« er et mønster, der ligger i en tekst, eller om det er et mønster, der ligger i den kultur, vi er en del af; og som vi (som professionelle læsere) har et bedre indblik $i$ og et bredere grundlag for at »interpretere «. Dette betyder, at vores status som »analytikere« er ændret. Som Fish (lettere affekteret) udtrykker det:

»Litteraturkritikeren er ikke mere den ydmyge tjener for nogle tekster, hvis glorværdighed eksisterer uafhængigt af, hvad han kan finde på; det er det, som han gør - inden for de begrænsninger, der ligger i den litterære institution - som giver tekster eksistens og gør dem tilgængelig for analyse og værdsættelse. Litteraturkritikkens praksis er ikke noget, man skal undskylde; den er absolut essentiel ikke kun for vedligeholdelsen af, men for selve frembringelsen af de objekter, den vier sin opmærksomhed $\ll(I T T C$ p.368).

Vi er medvirkende til, at rammerne for de interpretive fællesskaber udvikles og sprænges. Man kan sige, at til den ene side er vi med til at skabe normer for, hvordan tekster læses, og til den anden, hvordan de skrives.

Grænsen mellem objekt (tekst) og »analyse« er altså udvisket. Man kan som Harold Bloom hævde, at al kritik blot er en ny tekst, et nyt digt. Hvis man ser på, hvordan udseendet af analyser har udviklet sig de sidste tyve år, er det meget tydeligt at denne bevidsthed har sat sine spor. Dekonstruktionen er et af de bedste eksempler. Den synes at søge ud i grænseområderne for, hvad vores interpretative fællesskaber kan acceptere, og gør det (for en stor dels vedkommende) i en æsteticeret udgave, der ville have rejst højlydt latter og uforståen- 
hed før i tiden. Som Jonathan Culler siger det: »Interpretation har ikke selv brug for noget forsvar; den er altid til stede, men som de fleste intellektuelle aktiviteter er en interpretation kun interessant, når den er yderliggående. « ${ }^{30} \mathrm{Og}$ samtidig viser analyseme i høj grad, at vi befinder os i en tidsalder, hvor sandhed, objektivitet og perception problematiseres. Men dette er langt fra ensbetydende med, at vi ikke vil forlade denne position, dette fællesskab, igen. Opløsningen har allerede vist sig, ved f.eks den udbredte interesse, der synes at eksistere for historiske tilgange i de selvsamme litteraturteoretiske miljøer, som både Fish og dekonstruktionen kom fra. Men den radikale afskrivning af faste værdier i teksten har sat dybe spor; institutionen består, men dens arbejdsgrundlag er ændret, hvilket kommer til udtryk i en retning som Stephen Greenblatts »New Historicism«. Denne viser, at man udmærket kan tage de forbehold som både Fish og dekonstruktionen fordrer med i sine overvejelser og dermed arbejde $\mathrm{i}$ vished om, at fremstillingen af historien altid vil være konstruktioner; at det er historikeren, der bestemmer hvilken historie der fortælles, hvorfor ny-historikeren må foretage forskellige læsninger af de tekstlige spor, han er i besiddelse af.

Afslutningsvis skal et ikke ubetydeligt problem ved hele Fishs meta-teoretiske projekt nævnes. Hvis hans påstand er, at intet er mere sandt end andet, da er selve denne påstand jo heller ikke mere rigtig, end den der benægter den. Sagt anderledes: Bliver Fish ikke fanget i sit eget net ved at påstå, at intet er sandt, alt er overtalelse? Han er dog udmærket klar over dette problem, og kunne svare på det med følgende:

»Svaret er ja; men svaret er også »og hvad så? « I følge den position, som her er blevet lagt frem, kan ingen gøre krav på forret for det synspunkt, han indtager, og derfor er enhver tvunget til at praktisere overtalelsens kunst. Dette galder også mig, og overtalelse er den kunst, som jeg har forsøgt at praktisere her« (ITTC, p.368).

\section{Noter}

1. Hans Hauge: »En introduktion til Stanley Fish « in Kritik nr. 73, 1985.

2. Poul Behrendt: »Portræt af min læser« in Kritik nr. 73, 1985, p.46.

3. Henrik Nordbrandt: $\gg$ Et brev... « in Kritik nr. 73, 1985, p.90.

4. Pil Dahlerup: Dekonstruktion. 90'ernes litteraturteori, Kbh. 1991, p.12.

5. Jørgen Dines Johansen: »Fortvivlelse eller agtelse. Nogle tendenser og problemer $i$ den aktuelle litteraturvidenskab « in $K \& K$ nr. 65-66, 1989, p.119. Dines Johansens artikel behandler også Paul de Man og Roland Barthes, som begge er medregnet i denne karakteristik.

6. I forhold til ovenstående skal det dog nævnes, at der - trods alt - også findes folk, 
som finder Stanley Fishs projekt for - om ikke »sandt«, da - relevant. På dansk grund kan - ud over Hans Hauges introduktion som allerede er omtalt - nævnes bl.a. Jan Fogh Mikkelsens lidt bredere indgang til læser-respons teorien (»Læseren og litteraturen. En introduktion til reader-response criticism « in Litteratur \& Samfund nr. 46) og Peter Bornedals diskussion af Hauges introduktion (»Den uendelige fortolkelighed « in Den Blå Port nr. 11, 1989) nævnes.

7. Stanley Fish: Is There a Text in This Class. The Authority of Interpretive Communities, Cambridge, Mass. 1980 (herefter forkortet ITTC).

8. I danske oversættelser vælger man normalt at oversætte »interpretive communities« til »fortolkningsfællesskaber«. Denne oversættelse er dog ikke helt tilfredsstillende, da den fjerner den »dynamik « Fish's begreb indeholder, i kraft af at »interpretive« kan betyde »fortolkende«. Jeg vælger derfor at lægge min danske udgave »tættere« på Fishs ved at benytte »interpretative fællesskaber«.

9. Stanley Fish: Surprised by Sin. The Reader in Paradise Lost, Berkeley 1972 (2. udg.).

10. En lignende strategi er Roland Barthes' læsning i S/Z. Fish gør selv opmærksom på, at Barthes har øvet en vis indflydelse på ham (ITTC p.21).

11. Chomskys betydning er stor, men det er en anden sprogteori, der virkelig har sat Fish i gang: J.L. Austins (og John Searles) talehandlingsteori. (Fish gør opmærksom på, at han og Searle var kolleger på University of California, og desuden er Is There a Text in This class? fyldt med eksplicitte referencer til Austin \& Searle; bl.a. kan nævnes essayet »How To Do Things with Austin and Searle« (ITTC p. 197).) Talehandlingsteorien siger (blandt andet), at en sætning aldrig står for sig selv, men kun betyder i kraft af den kontekst den optræder i. Fører man dette over i en litteraturteoretisk debat, kommer nykritikkens autonomi-begreb gevaldigt $i$ klemme. Det er formentlig denne bevægelse Fish har foretaget, når han i sin affektive stilistik vil aflæse læserens reaktion.

12. Jeg skal ikke kunne sige, om Fish er under påvirkning af Jacques Derrida, som hævder noget lignende om sin dekonstruktion. Skulle man lave en videre diskussion af, om Fishs »metode« er en metode, vil resultatet blive et ordkløveri, som jeg helst vil undgå. Jeg tillader mig derfor at betegne »metoden« som en metode, og undskylder hvis det forvrænger.

13. Jonathan Culler: The Pursuit of Signs. Semiotics, Literature, Deconstruction, Ithaca 1981, p.129-130.

14. Denne iagtagelse giver andetsteds anledning til en bredere kritik af Fishs projekt. Her hævder Culler direkte, at Fishs analyser er konstruerede med det formål, at påvise hans teori. Fishs læsninger er ikke dem han egentlig producerer, men derimod konstruktioner, der viser hvordan en »Fishiansk læser« læser. »Or perhaps we ought to say, since a Fishian reader is a reader who holds himself to a particular role, that his accounts of the reading experience are reports of Fish reading as a Fishian reader reading as a Fishian reader. (Jonathan Culler: On Deconstruction. Theory and Criticism after Structuralism, Ithaca 1982, p.66.) Det skal dog lige tilføjes, at dette ikke kun er ment som kritik af Fish, men er et generelt synspunkt fra Culler: »To read is to play the role of a reader and to interpret is to posit an experience of reading « (ibid. p.67).

15. »How Ordinary is Ordinary Language «, ITTC p. 97.

16. Behrendt p.48 (se note 2).

17. Tanner Lectures and Seminars, Cambridge, 1990. Seminarets officielle $» k o m b a t-$ tanter« var Umberto Eco (som var »hovedattraktion« og »-person«), Richard Ror- 
ty, Jonathan Culler og Christine Brooke-Rose. Umberto Eco et al.: Interpretation and overinterpretation, Cambridge 1992.

18. Eco, p. $145 \mathrm{f}$.

19. Det skal dog straks tilføjes, at disse »absurde« tilfælde faktisk ikke behandles hos Fish, hvilket sikkert skyldes hans pragmatiske indgangsvinkel. Hans argumentationer er i høj grad »logisk « opbyggede, hvorfor situationer som den Eco frembringer, overhovedet ikke bliver taget i betragtning. Man kunne dog forestille sig, at Fish ville have undgået nogle af de misforståelser, han har været genstand for, hvis han mere eksplicit havde giort opmærksom på, at der er grænser for, hvad man kan betegne som interpretation.

20. Listen ser ud som f $\varnothing$ lger: Jacobs-Rosenbaum, Levin, Thorne, Hayes, Ohman (?). Spørgsmålstegnet skyldes, at Fish var i tvivl om, hvorvidt Ohman er med enkelt eller dobbelt $n$ (- navnene var sat op under hinanden).

21. Katastrofeteorien (udformet bl.a. af Jean Petitot) er en »strukturalistisk« analyse, der bl.a. bruger modeller overtaget fra termodynamikken, jfr. Frederik Stjernfelt: Formens betydning, Kbh. 1992.

22. Tzvetan Todorov: »Mod antihumanismen i litteraturkritikken« in Fredag nr. 21, 1989.

23. Man vil nok rettere fremhæve William James, som grundlæggende for neopragmatismens værdikritiske fundament, men Rorty har mange eksplicitte referencer til Nietzsche, hvorfor jeg vil godtage Todorovs karakteristik.

24. Todorov p. 47.

25. Der synes at være en tendens til, at man stiller Derridas dekonstruktion og den amerikanske/litterære lig hinanden. Denne sammenstilling er jeg ikke helt enig $i$, for hvor Derridas arbejde er af en overvejende filosofisk karakter og samtidig synes at være imod enhver form for metodetænkning, er den amerikanske først og fremmest en litterær analysestrategi, der i højere grad arbejder metodologisk. Man kan (med fare for at generalisere) sige, at den amerikanske dekonstruktion er en »formalisering « af den derridaske.

26. Her ifølge Florian Rötzers interview med Derrida in Samtaler med franske filosoffer, Kbh. 1988.

27. Dette og følgende eksempel på sammenfald mellem Fish og Derrida er ansporet af Hauge (se note 1); Dahlerup (se note 4) og Bornedal (se note 6).

28. Uden at ville starte en tænkt diskussion mellem Derrida og Fish kunne man dog godt forestille sig, at Derrida ville indvende, at hans dekonstruktive lasninger er udtryk for immanent kritik; at han - udtrykt fishiansk - indlæser sig i det interpretive fællesskab teksten synes at tilhøre, for derved at kunne afsløre dens metafysik. Hvorvidt Fish vil acceptere dette, må jeg af gode grunde lade være usagt. Men jeg tvivler...

29. Det skal dog tilføjes, at Fish intetsteds selv anfører dette som en dekonstruktion.

30. Jonathan Culler: »In defence of overinterpretation« in Umberto Eco et al.: Interpretation and overinterpretation, Cambridge 1992, p.110. 